Original Article

RHs: DONATIELLO ET AL.

ORIGINAL ARTICLE

\title{
CEO talent: A dime a dozen, or worth its weight in gold? ${ }^{1}$
}

\section{Nicholas E. Donatiello | David F. Larcker | Brian Tayan}

Stanford Graduate School of Business, Stanford University, Stanford, California, USA

Emails: nd@odysseylp.com; dlarcker@stanford.edu; btayan@ stanford.edu

This is the author manuscript accepted for publication and has undergone full peer review but has not been through the copyediting, typesetting, pagination and proofreading process, which may lead to differences between this version and the Version of Record. Please cite this article as doi:10.1111/eufm.12158 
Abstract

Very little sophisticated research exists on the size, quality, and efficiency of the labor market for CEO talent. This paper sheds light on this labor market by considering the perspectives of directors directly responsible for hiring and firing the CEOs of the largest publicly traded corporations in the United States. We find that directors overwhelmingly believe that the CEO job is exceptionally challenging and only a handful of executives are qualified to run their company and others in their industry. This suggests that the labor market for outstanding CEO talent is significantly tighter and more competitive than governance experts might realize.

\section{KEYWORDS}

board of directors, CEO compensation, CEO labor market, CEO recruitment, CEO succession planning, corporate governance, internal talent development[AQ1]

\section{JEL CLASSIFICATION}

:G34

\section{1 | INTRODUCTION}

In recent years, there has been considerable criticism of the amount of money that CEOs earn to run the largest US companies. One prominent observer calls CEO pay 'out of control' (Lowenstein, 2017). Another claims that the rise of CEO pay is 'unstoppable' (Morgenson, 2013). According to a third, executive compensation is a 'first-order' problem that 'the selfcorrecting mechanisms of the market cannot be relied on' to fix ('Neither Rigged nor Fair,' 2016). Implicit in these criticisms is the idea that CEOs are overpaid relative to what they are worth to companies and their shareholders. Figure 1 shows the rise in total compensation paid to the CEOs of S\&P 500 companies from 1995 to 2015. Table 1 shows the relationship between total CEO compensation and company size by market cap.

[f]Fig. 1 about here[/f]

[t]Table 1 about here[/t]

Governance researchers have expended considerable resources examining executive compensation in an effort to determine whether pay levels are set fairly. They have studied the relations between CEO pay and performance, company size, average worker pay, the pay levels of senior executives just below the CEO, and the pay levels of other highly compensated professionals (such as hedge fund managers, private equity managers, lawyers, athletes, etc.) to determine whether CEO compensation is rewarded through an efficient process or is indicative of governance failure. The results of these studies are generally mixed. ${ }^{1}$

An important and related question, however, is rarely asked: Just how scarce is CEO talent? How many people are very well qualified to run a large, publicly traded company? Stated differently, what is the size of the qualified labor pool for talent in a given industry, and how difficult is it to identify, attract, and recruit those qualified to serve as CEO? These questions have important implications not only for CEO pay levels, but also for the efficiency of the CEO labor market, succession planning, and internal talent development and retention.

\section{2 | CEO TALENT POOL}

The perspectives of corporate directors are critical for understanding the depth and quality of the CEO labor market. As corporate overseers, directors are highly knowledgeable about the number, quality, and performance of top talent in their industry - both internal to their 
company and across their peer set. Through regular succession planning discussions, they should have identified specific individuals or candidate pools to turn to in an emergency or scheduled transition. They are also directly responsible for evaluating talent, making CEO hiring and firing decisions, and closely monitoring performance.

For these reasons, Stanford Graduate School of Business and the Rock Center for Corporate Governance at Stanford University conducted a survey of directors currently serving on the boards of the largest 250 US companies by revenue (Fortune 250) to better understand their perspective of the size and quality of the labor market for CEO talent. ${ }^{2}$

The survey finds that directors overwhelmingly believe that the CEO job is very difficult and that only a small handful of executives are qualified to run companies in their industry. Almost all directors (98\%) describe the CEO job at their company as extremely or very challenging. Practically none $(2 \%)$ believe it is moderately, slightly, or not at all challenging (see Figure 2).

[f]Fig. 2 about here[/f]

When asked to estimate how many executives are capable of stepping into the CEO role at their company and performing at least as well as their current $\mathrm{CEO}$, directors estimate that fewer than four executives have the requisite skills (see Figure 3). Their assessment of a small labor market is not confined to their own company and extends to other companies in their industry. When asked how many executives could step into the CEO role of their biggest competitor and perform at least as well as that company's CEO, directors estimate that only six executives would be qualified (see Figure 4). They also believe that only nine executives would have the skills needed to turn around a company struggling in their industry (see Figure 5).

[f]Fig. 3 about here[/f]

[f]Fig. 4 about here[/f]

[f]Fig. 5 about here[/f]

One respondent explains: 'The CEO role is difficult and increasingly complex. Finding truly qualified talent in recent years has gotten more difficult.' According to another, CEO talent is 'difficult to vet and costly if you make a mistake.... The risk of selecting the "wrong" candidate is greater than any time in the past.' A third emphasizes the difficulty that newly promoted executives have in getting up to speed as CEO: 'There is no such thing as "stepping" into a CEO role.' Cultural fit is also seen as a limiting factor: 'I am less concerned about talent being available than I am about the cultural fit of outside talent.'

Fortune 250 directors strongly agree that CEOs in their industry have 'specific skills that are extremely hard to replicate,' rating this statement a 7.5 on a scale of $1-10$ (with 10 indicating that it completely reflects their point of view and 1 indicating that it does not at all reflect their point of view). They also believe that both general management expertise and industry expertise are 'critical for being a successful CEO,' assigning these scores of 9 and 8 , respectively. Furthermore, they believe having top talent is critical for their company's overall success, agreeing that 'it is impossible to be the top company in our industry without having the top CEO in our industry' (7 on a scale of $1-10) .^{3}$

At the same time, many admit that it is not easy to evaluate CEO talent. On average, directors believe that:

it is difficult to evaluate prospective CEO talent during a search process because a candidate might meet all the criteria in terms of previous work 
experience but it is still hard to tell whether he or she would be a successful CEO. (7 on a scale of $1-10$ - see Table 2)

[t]Table 2 about here[/t]

One respondent explains that, 'CEO talent is very difficult to identify by resume, particularly for mega-cap companies.' Another believes that, 'It is hard to judge talent before it is challenged. Many can run a company if things are going well and the economy is healthy. The real test is when things aren't going well and the economy is not supportive.' According to another, 'Even internal candidates can deviate from expectations once they are in the big job.'

Directors offer more varied assessment of the size of the labor pool when asked to estimate the number of people who could replace the CEOs of prominent companies not in their industries, although the numbers are still exceedingly small. Of note, they believe that replacing visionary founder CEOs is significantly more difficult than the professional managers who oversee large blue chip corporations. For example, they believe Jeff Bezos of Amazon to be the most difficult CEO to replace, estimating that only two individuals could serve as viable replacements for him. Other visionary founder CEOs - such as Warren Buffett of Berkshire Hathaway, Elon Musk of Tesla, and Larry Page of Alphabet (Google) receive similarly small assessments. By contrast, they estimate the size of the labor market for more established companies such as ExxonMobil and General Motors to average between 10 and 15 candidates (see Figure 6). They also believe that technology and traditional retail are by far the most difficult industries for finding highly qualified CEOs - technology because it requires specific skills and retail because it is facing new competitive threats (see Figure 7).

[f]Fig. 6 about here[/f]

[f]Fig. 7 about here[/f]

These findings have important implications for corporate governance:

- Efficiency of the labor market for CEO talent. Given the scarcity of outstanding CEO talent among large corporations, it is unlikely that the labor market for CEOs functions efficiently. That is, the matching process for linking qualified talent with suitable job opportunities likely does not occur as economically as it does for other job types. With an inefficient labor market, management might face less pressure to perform and distortions can arise in the balance of power between the CEO and the board, and in compensation.

- Compensation. A tight labor market for CEO talent might help to explain high compensation levels, particularly among the largest US companies. If only a limited number of executives are qualified to run these companies - and if outstanding CEO talent is critical for their success - then it is reasonable to expect that boards will offer large sums of money to attract their top candidate or retain their current CEO. The cost of losing him or her to a competitor would be too high.

- Performance evaluation. Directors' view that capable CEO candidates are extremely scarce is likely to color their assessment of their CEO's performance as any evaluation that implies that the CEO should be replaced requires the board to take on the risk associated with finding a replacement. This risk aversion may encourage boards to tolerate both performance and behavior that would not be 
acceptable if they perceived the existence of a large pool of highly qualified candidates.

- Succession planning. If directors believe that executives require special and rare attributes that are difficult to identify (including the right set of functional, industry, and managerial experience combined with leadership qualities and cultural fit), identifying these candidates prospectively becomes even more important and reinforces the need for rigorous succession planning.

- Talent development and retention. Internal executives continue to be the most promising source of candidates for most companies when it comes to future succession. Given the board's familiarity with them, the visibility of their track record, and their tested cultural fit, it is more economic for most companies to invest in - and retain - their best internal talent.

\section{3 | CONCLUSIONS}

Governance experts have vigorously debated the appropriateness of CEO compensation in recent years. And yet, very little sophisticated insight exists into the size, quality, and efficiency of the labor market for CEO talent, which is a key determinant of pay. This paper attempts to shed light on the answers to these questions by considering the perspectives of the directors who are directly responsible for hiring and firing decisions at the largest publicly traded corporations in the United States.

The survey evidence presented in this paper finds that directors overwhelmingly believe that the CEO job is exceptionally challenging and that only a handful of executives are qualified to run their company and others in their industry. This suggests that the labor market for outstanding CEO talent is significantly tighter and more competitive than governance experts might realize. This raises a series of questions about the labor market for CEO talent. First, what is the cause of this labor shortage: inadequate talent development or an inability to accurately assess a candidate's skills and fit prior to promotion? How should companies change their strategic approach to talent development to increase the supply of viable CEO talent?

Second, the survey data presented in this paper only considers the perspective of very large, complex corporations. Do these results generalize to small- or mid-cap companies? Does the size of the CEO labor market grow as you move down the spectrum to smaller companies? If so, how much larger is it, and how does this influence the compensation, succession planning, and the other governance issues raised in this paper?

Third, the research cited in this paper attempts to assess the labor market for CEO talent by directly measuring perceptions of the directors who are responsible for making hiring and firing decisions.

Does a director's extreme familiarity with their company and industry make them well informed about the number of potential replacements for their CEO, or does it bias them into believing that their CEO is more irreplaceable than he or she actually is?

The labor market for CEOs remains an underdeveloped area of study. We believe this paper provides important perceptual data that lays the groundwork for future research into this topic, with important implications for corporate governance.

\section{ENDNOTES}

${ }^{1}$ For a review of the research on executive compensation, see Larcker and Tayan (2017).

2 Surveys were mailed to 1,100 directors and responses were received from 113 , representing a fairly high response rate of $10.3 \%$ for a study of busy respondents. The data and quotations in this Closer Look are derived from: Stanford Graduate School of Business and Rock Center for Corporate Governance at Stanford University (2017). 
${ }^{3}$ In contrast to some management research, directors consider CEOs a key determinant of whether the company is successful or not. See Larcker and Tayan (2016).

References

Larcker, D. F., \& Tayan, B. (2016). CEO attributes and firm performance (Quick Guide Series, Research Spotlight). Stanford, CA: Corporate Governance Research Initiative.

Larcker, D. F., \& Tayan, B. (2017). CEO pay levels (Quick Guide Series, Research Spotlight). Stanford, CA: Corporate Governance Research Initiative.

Lowenstein, R. (2017, April 18). CEO pay is out of control. Here's how to rein it in. Fortune.

Morgenson, G. (2013, June 29). An unstoppable climb in CEO pay. New York Times.

Neither rigged nor fair. (2016, June 25). The Economist.

Stanford Graduate School of Business \& Rock Center for Corporate Governance at Stanford

University. (2017). CEO talent: America's scarcest resource? 2017 CEO Talent Survey.

TABLE 1 CEO total compensation and company size by market capitalization

\section{Firm size}

Top 100

$101-500$

$501-1,000$

$1,001-2,000$

$2,001-3,000$

$3,001-4,000$

$1-4,000$

\section{Total expected} compensation

$\$ 13,713,000$

$\$ 10,656,000$

$\$ 6,458,000$

$\$ 3,981,000$

$\$ 2,092,000$

$\$ 900,000$

$\$ 2,869,000$

\section{Market value}

$\$ 104,413,000$

$\$ 21,710,000$

$\$ 6,086,000$

$\$ 2,016,000$

$\$ 624,000$

$\$ 144,000$

$\$ 1,143,000$ 
TABLE 2 Fortune 250 director perception of the labor market for CEO talent

This table reports the responses that Fortune 250 directors provided to a series of questions about the labor market for CEO talent. Respondents were asked, 'How well do each of the following statements reflect your point of view?' and instructed to assign a number on a scale of 1-10, with 10 indicating that the statement 'completely reflects my point of view' and 1 indicating that the statement 'does not at all reflect my point of view.' Average and median results are provided, with statements presented in descending order of agreement.

In our industry, having general-management expertise is critical for being a successful CEO

In our industry, having industry-specific expertise is critical for being a successful CEO

CEOs in our industry have specific skills that are extremely hard to

It is difficult to evaluate prospective CEO talent during a search process because a candidate might meet all the criteria in terms of previous work experience but it is still hard to tell whether he or she would be a successful CEO

In our industry, you can win if the CEO is among the top three. He or she doesn't need to be number one

It is impossible to be the top company in our industry without having the top CEO in our industry

CEOs in our industry have leverage over pay packages because talent is scarce

CEOs in our industry are responsible for the vast majority of value created at their companies

Top executives in our industry have so much unvested equity that it is hard to recruit them to another company
Average

8.5

8.2

7.5

7.4

Median

9.0

9.0

7.3

7.2

7.0

6.3

6.2

6.0 
FIGURE 1 CEO total compensation among S\&P 500 companies: 1995-2015. Median values. Data 2010-2015 from: Equilar CEO Pay Trends; Data 1995-2009 from: Kevin Murphy, 'Executive Compensation: Where We Are, and How We Got Here.' In G.

Constantinides, M. Harris, \& R. Stulz (Eds.), Handbook of the Economics of Finance. Amsterdam, Netherlands: Elsevier Science North-Holland (2012)[AQ2]

FIGURE 2 Survey data in response to the question, 'In general, how challenging is the job of CEO at your company?'

FIGURE 3 Survey data in response to the question, 'Roughly how many people, including those both inside and outside your company, are capable of stepping into the CEO role at your company today and doing at least as well as your current CEO?'

FIGURE 4 Survey data in response to the question, 'How many people, including those both inside and outside their company, are capable of stepping into the CEO role at your biggest competitor and doing at least as well as their current CEO?'

FIGURE 5 Survey data in response to the question, 'If a large company in your industry were in need of a turnaround, how many people have the skills required to succeed as its CEO?'

FIGURE 6 Survey data in response to the question, 'Based on what you know about the companies below, how many people are capable of stepping into the CEO role today and doing at least as well as the current CEO?'

FIGURE 7 Survey data in response to the question, 'Is there a single industry (other than your own) in which it is most difficult to find CEO talent?' Unaided 


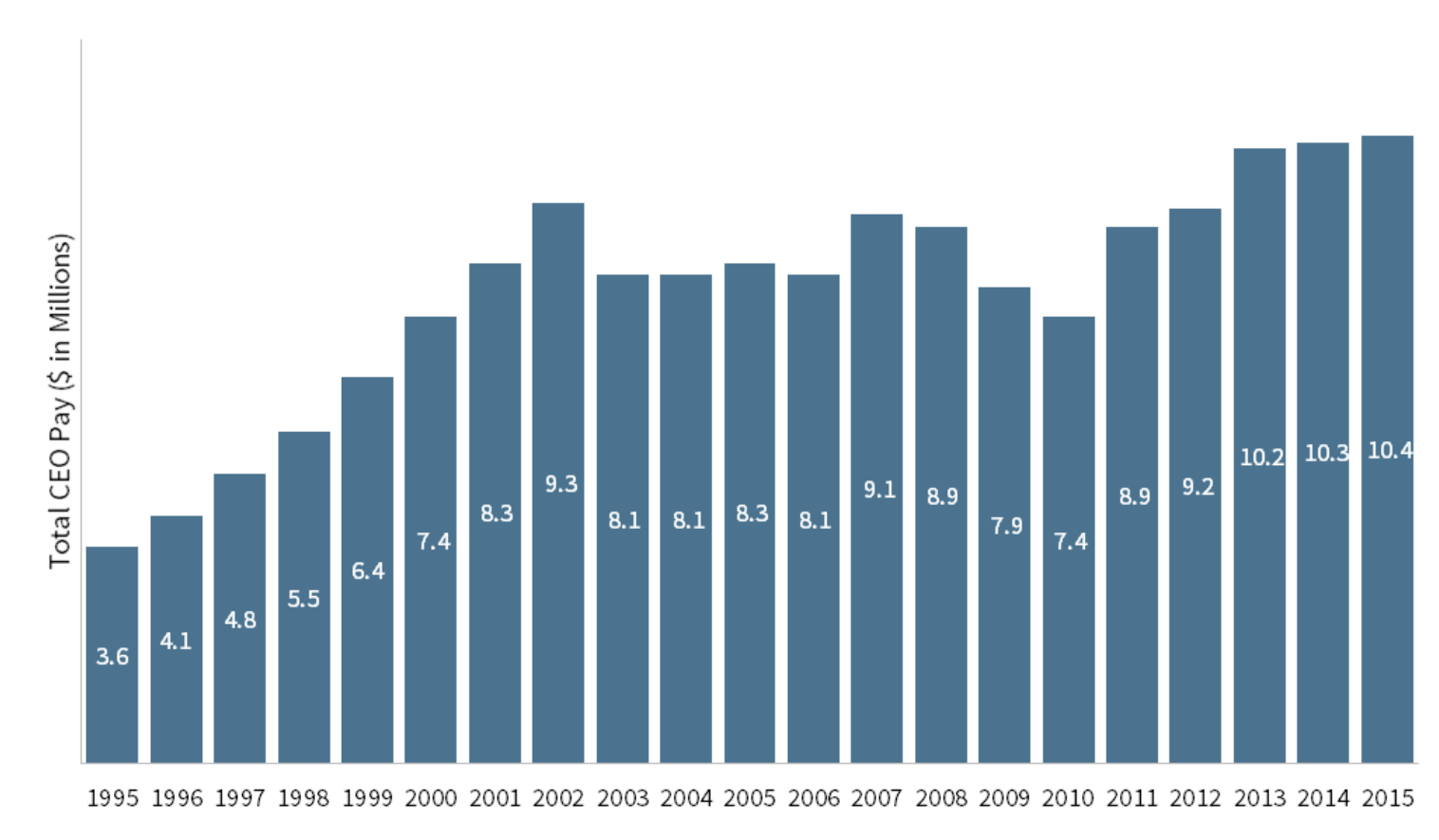

Fig. 1 


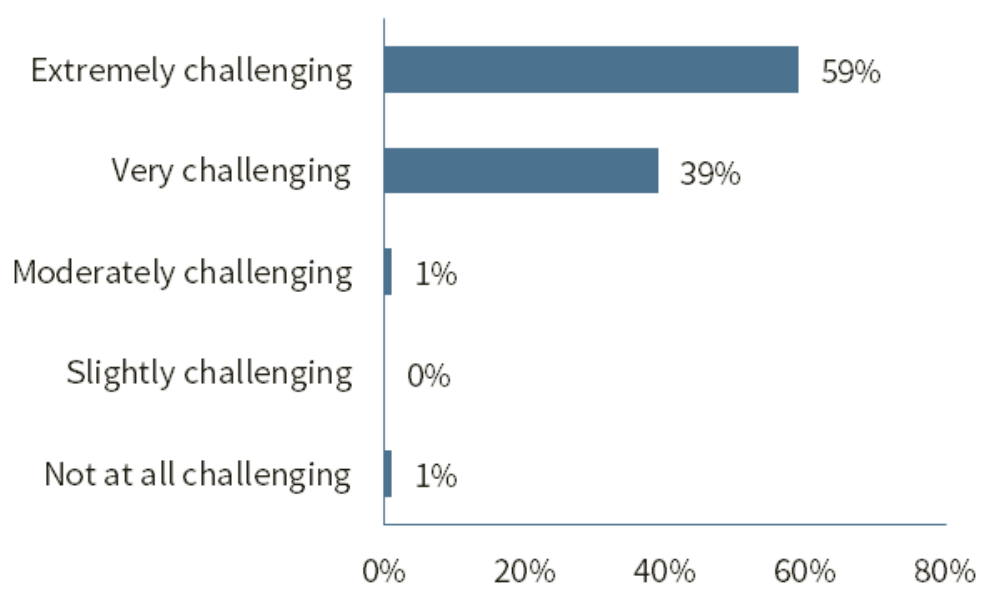

Fig. 2 


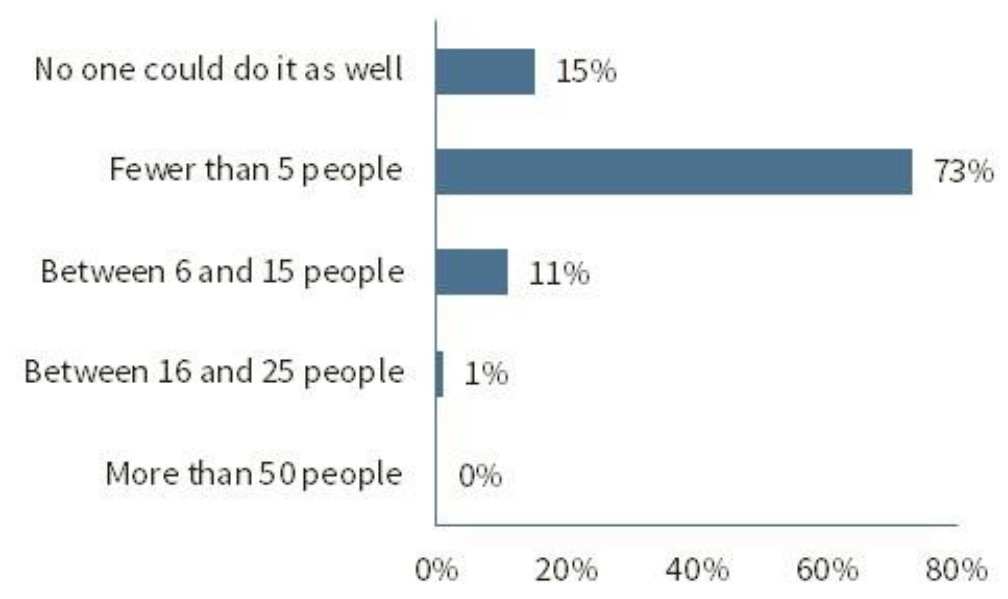

Fig. 3

This article is protected by copyright. All rights reserved. 

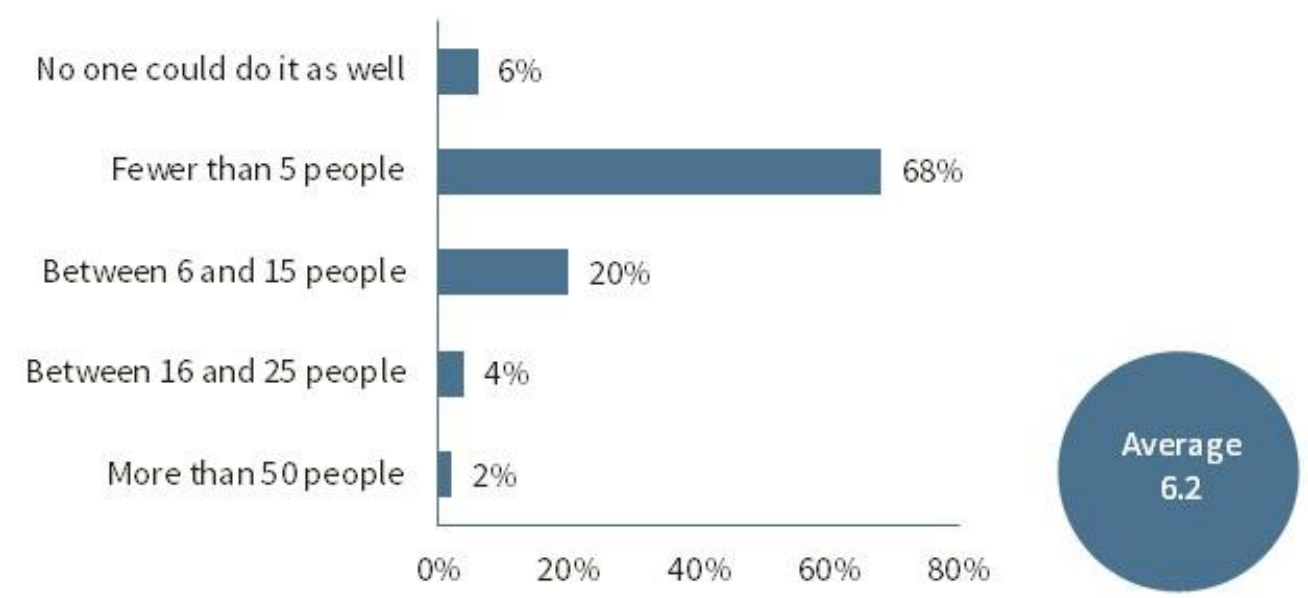

Fig. 4 

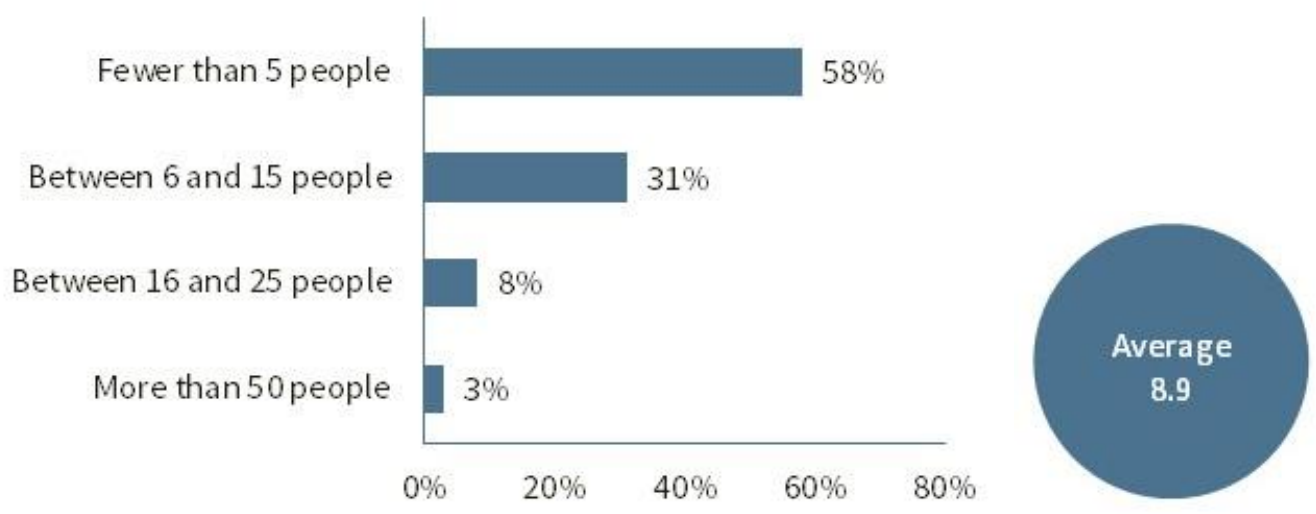

Fig. 5

This article is protected by copyright. All rights reserved. 


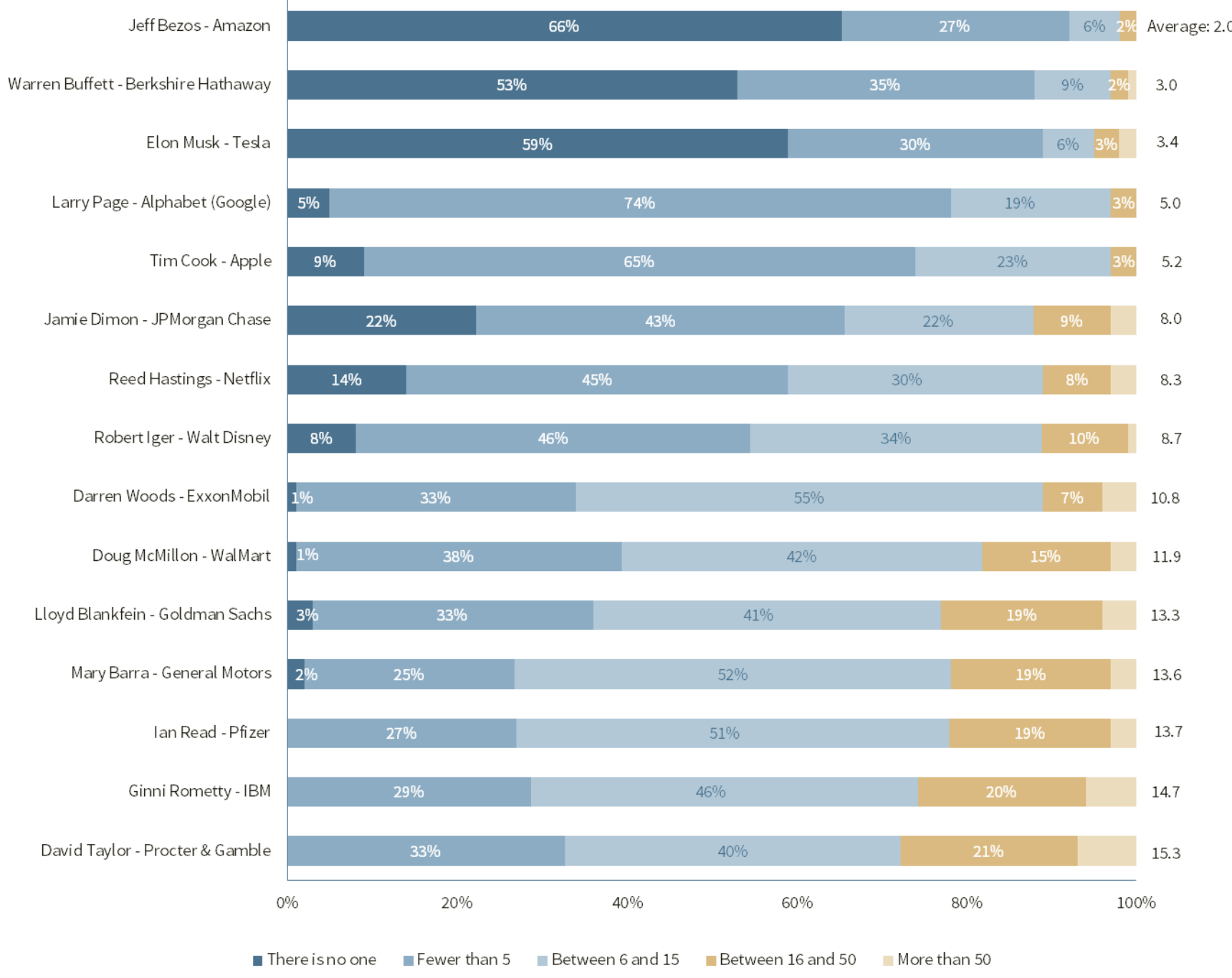

Fig. 6 


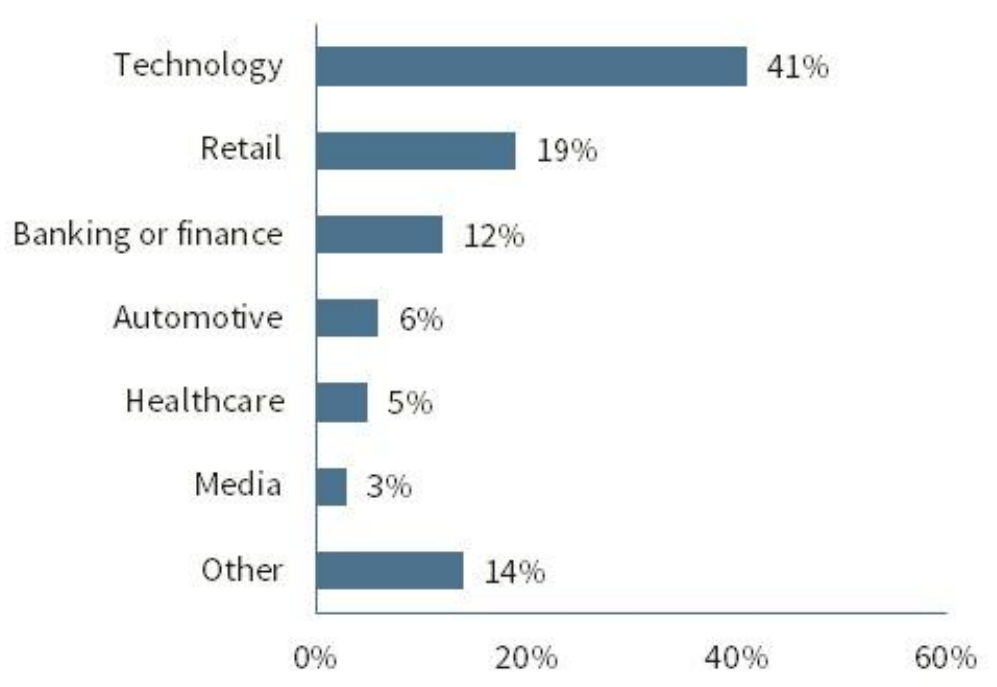

Fig. 7

This article is protected by copyright. All rights reserved. 


\section{University Library}

\section{- M M I N E R VA A gateway to Melbourne's research publications}

Minerva Access is the Institutional Repository of The University of Melbourne

Author/s:

Donatiello, NE;Larcker, DF;Tayan, B

Title:

CEO talent: A dime a dozen, or worth its weight in gold?

Date:

2018-06-01

Citation:

Donatiello, N. E., Larcker, D. F. \& Tayan, B. (2018). CEO talent: A dime a dozen, or worth its weight in gold?. European Financial Management, 24 (3), pp.301-308. https:// doi.org/10.1111/eufm. 12158 .

Persistent Link:

http://hdl.handle.net/11343/294046 